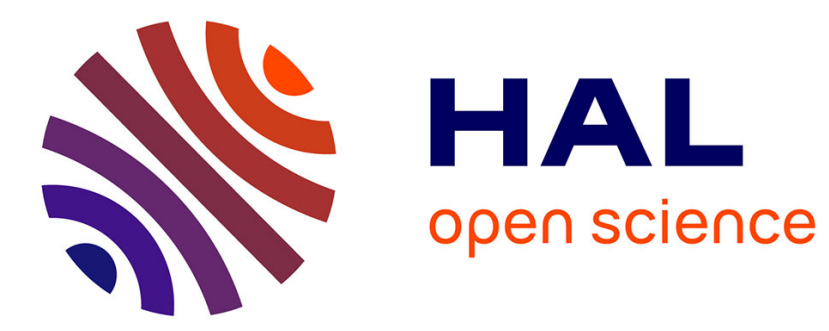

\title{
Seed oil bodies from Gevuina avellana and Madia sativa
}

Francisca F. Acevedo, Monica M. Rubilar, Carolina C. Shene, Patricia P. Navarrete, Fernando F. Romero, Claudia C. Rabert, Pascale P. Jolivet, Benoit B. Valot, Thierry T. Chardot

\section{- To cite this version:}

Francisca F. Acevedo, Monica M. Rubilar, Carolina C. Shene, Patricia P. Navarrete, Fernando F. Romero, et al.. Seed oil bodies from Gevuina avellana and Madia sativa. Journal of Agricultural and Food Chemistry, 2012, 60 (28), pp.6994-7004. 10.1021/jf301390d . hal-01000351

\section{HAL Id: hal-01000351 https://hal.science/hal-01000351}

Submitted on 29 May 2020

HAL is a multi-disciplinary open access archive for the deposit and dissemination of scientific research documents, whether they are published or not. The documents may come from teaching and research institutions in France or abroad, or from public or private research centers.
L'archive ouverte pluridisciplinaire HAL, est destinée au dépôt et à la diffusion de documents scientifiques de niveau recherche, publiés ou non, émanant des établissements d'enseignement et de recherche français ou étrangers, des laboratoires publics ou privés. 


\section{Seed Oil Bodies from Gevuina avellana and Madia sativa}

Francisca Acevedo, ${ }^{* \dagger, \ddagger}$ Mónica Rubilar, ${ }^{\dagger, \dagger}$ Carolina Shene, ${ }^{\dagger, \ddagger}$ Patricia Navarrete, ${ }^{*}$ Fernando Romero, ${ }^{\#}$ Claudia Rabert, ${ }^{\dagger}$ Pascale Jolivet, ${ }^{\S, \otimes}$ Benoît Valot, ${ }^{\perp, \|, \triangle, \nabla}$ and Thierry Chardot ${ }^{\S, \otimes}$

${ }^{\dagger}$ Center of Food Biotechnology and Bioseparations, BIOREN, Universidad de La Frontera, Casilla 54-D, Temuco, Chile

${ }^{\ddagger}$ Agriaquaculture Nutritional Genomic Center, CGNA (R10C1001), Technology and Processes Unit, Francisco Salazar 01145, Universidad de La Frontera, Temuco, Chile

${ }^{\#}$ Center of Neurosciences and Peptides Biology-CEBIOR, BIOREN, Universidad de La Frontera, Casilla 54-D, Temuco, Chile

${ }^{\S}$ INRA, UMR1318, Institut Jean-Pierre Bourgin, Saclay Plant Sciences, RD10, F-78000 Versailles, France

${ }^{\otimes}$ AgroParisTech, Institut Jean-Pierre Bourgin, Saclay Plant Sciences, RD10, F-78000 Versailles, France

${ }^{\perp}$ INRA, UMR0320 Génétique Végétale, Plateforme d'Analyse Protéomique de Paris Sud, Ferme du Moulon, F-91190 Gif-sur-Yvette, France

"CNRS, UMR8120 Génétique Végétale, Plateforme d'Analyse Protéomique de Paris Sud, Ferme du Moulon, F-91190 Gif-sur-Yvette, France

$\triangle$ Université Paris-Sud, Plateforme d'Analyse Protéomique de Paris Sud, Ferme du Moulon, F-91190 Gif-sur-Yvette, France

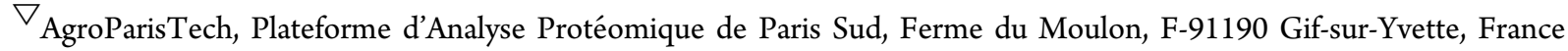

Supporting Information

ABSTRACT: In this study, oil bodies (OBs) from Gevuina avellana (OBs-G) and Madia sativa (OBs-M) were isolated and characterized. Microscopic inspection revealed that the monolayer on OB-G was thinner compared to that on OB-M. Cytometric profiles regarding size, complexity, and staining for the two $\mathrm{OB}$ sources were similar. Fatty acid to protein mass ratio in both OBs was near 29, indicating high lipid enrichment. OBs-G and OBs-M showed a strong electrostatic repulsion over wide ranges of $\mathrm{pH}$ (5.5-9.5) and $\mathrm{NaCl}$ concentration $(0-150 \mathrm{mM})$. Proteins displaying highly conserved sequences (steroleosins and aquaporins) in the plant kingdom were identified. The presence of oleosins was immunologically revealed using antibodies raised against Arabidopsis thaliana oleosins. OBs-G and OBs-M exhibited no significant cytotoxicity against the cells. This is the first report about the isolation and characterization of OBs-G and OBs-M, and this knowledge could be used for novel applications of these raw materials.

KEYWORDS: oil bodies, oleosins, Gevuina avellana, Madia sativa

\section{INTRODUCTION}

Oleosomes from plant seeds are oil bodies (OBs) that act as energy stores for postgerminative growth. ${ }^{1}$ OBs consist of an oil core with a matrix of triacylglycerol (TAG) bound by a phospholipid monolayer embedded with proteins known as oleosins. ${ }^{1}$ Oleosins are considered to be highly stable with natural self-emulsifying properties derived from alternating amphipathic and hydrophobic domains. ${ }^{1}$ It has been tacitly assumed that oleosins maintain $\mathrm{OBs}$ as individual units to provide a high surface-to-volume ratio that would facilitate lipase access during germination. ${ }^{2}$

OBs obtained from oilseeds have been exploited for several biotechnological applications ${ }^{3,4}$ on the basis of their noncoalescing nature, ease of extraction, and presence of oleosins. ${ }^{5}$ In food products, OBs could serve as healthier and more economical alternatives to emulsifying agents, particularly when they have high contents of polyunsaturated fatty acids and antioxidants such as $\alpha$-tocopherol. ${ }^{6}$ OB-based pharmaceutical formulations include therapeutic, diagnostic, and delivery agents. $^{7-9}$ OBs have been used as carriers for hydrophobic molecules in nutraceuticals, ${ }^{10}$ pesticides, ${ }^{11}$ flavors, ${ }^{12}$ and pharmaceutical applications; in addition, they have been successfully tested as a biocapsule for probiotics. ${ }^{13}$

OBs and oleosins have been purified and characterized in seeds of many plant species, such as Arabidopsis thaliana, ${ }^{14}$ Jatropha curcas, $^{15}$ maize, ${ }^{16}$ sunflower, ${ }^{17}$ rapeseed, ${ }^{18,19}$ and soybean. $^{20}$

Chilean Amerindians (the Mapuche people) have used Gevuina avellana and Madia sativa seeds as oil sources since pre-Columbian times, but there are very few scientific reports that describe their bioactive molecules. ${ }^{21,22}$ In addition, both are native species that can be economically exploited.

G. avellana Mol., a Chilean hazelnut, belongs to monospecific genera of the Proteacea family found in the native forest of the Andes and Coastal mountains in southern Chile. ${ }^{23}$ Their fruits (edible nuts) have a great commercial potential in the cosmetic, pharmacological, and food industries because of the high content of bioactive and nutritive substances. The seeds contain

Received: March 31, 2012

Revised: June 20, 2012

Accepted: June 22, 2012

Published: June 22, 2012 
$12 \%$ proteins, $24 \%$ carbohydrates, and a high oil percentage $(40-49 \%) .^{24}$ In Chile, they are consumed as toasted seeds.

M. sativa Mol. has been classified as a weed; it is found in central Chile. Natives process the seeds to obtain edible oil. ${ }^{22}$ M. sativa belongs to the Astereacea family, and its seeds present approximately $29 \%$ protein, $26 \%$ lipids, $24 \%$ fiber, and $14 \%$ total carbohydrates. ${ }^{22}$ Furthermore, both native seeds are an interesting source of oil bodies.

The objective of this study was to characterize proteins and lipids of seed oil bodies from the nonsequenced species $G$. avellana and $M$. sativa and to evaluate their stability and toxicity in cells.

\section{MATERIALS AND METHODS}

Plant Materials. Mature seeds from G. avellana were obtained from local producers (Villarrica, La Araucanía Region, southern Chile). Seeds from M. sativa were collected in the central region of Chile. Seeds were dried at $30{ }^{\circ} \mathrm{C}$ and stored at $4{ }^{\circ} \mathrm{C}$ until use. G. avellana seeds were manually dehulled before the isolation of $\mathrm{OBs}$.

Isolation of Oil Bodies. Isolation of OBs was performed according to the method of Jolivet et al. ${ }^{25}$ Seeds ( $400 \mathrm{mg}$ for G. avellana and 300 $\mathrm{mg}$ for M. sativa) were separately ground four times for $30 \mathrm{~s}$ in $5 \mathrm{~mL}$ of $100 \mathrm{mM}$ sodium carbonate containing $0.6 \mathrm{M}$ sucrose $(\mathrm{pH} 10.5)$ using a glass potter and a Teflon plunger driven by a Heidolph motor (rate 7). The samples were cooled in ice between each grinding cycle. The suspension was overlaid by $5 \mathrm{~mL}$ of sodium carbonate containing 0.4 $\mathrm{M}$ sucrose and spun at $10000 \mathrm{~g}$ and $4{ }^{\circ} \mathrm{C}$ for $30 \mathrm{~min}$ in a swingingbucket rotor (Beckman Coulter ultracentrifuge Optima L90K). The floating $\mathrm{OBs}$ fraction was resuspended in $1 \mathrm{~mL}$ of $0.4 \mathrm{M}$ sucrose sodium carbonate, overlaid by $100 \mathrm{mM}$ 4-(2-hydroxyethyl)-1piperazineethanesulfonic acid (HEPES) buffer ( $\mathrm{pH} 7.5)$ and spun as before. The floating OB fraction was once more spun in HEPES buffer. Finally, the OB fraction was suspended in a minimal volume of HEPES buffer and stored at $4{ }^{\circ} \mathrm{C}$ until further use.

Microscopy of Oil Bodies. OB suspension ( $10 \% \mathrm{v} / \mathrm{v})$ was observed using an Olympus CX41 light microscope equipped with a $100 \times$ oil immersion objective. Images were captured with a coupled camera (Micropublisher 3.3 RTV) and processed using Q.Capture pro 6.0 software. In addition, Nile red $(1 \mathrm{mg} / \mathrm{mL}$ in acetone) was added to an aliquot of the suspension. After $30 \mathrm{~min}$ of incubation at room temperature, the OBs were observed through confocal microscopy (Olympus Fluoview 1000, 488/583 nm argon laser, Olympus UPLSAPO $100 \times$ (oil immersion) objective). All of the settings for the confocal microscope and the imaging were computer-controlled (software FV-ASW 2.0).

The samples were imaged using transmission electron microscopy (TEM) (JEOL JEM-1200 EX 11, 120 KVolts, Camera Getan model 782, Erlangshen ES500WJEOL). The samples were diluted with $0.1 \mathrm{M}$ sodium cacodylate ( $\mathrm{pH} 6.8$ ) and fixed with 4\% glutaraldehyde for $1 \mathrm{~h}$ at room temperature followed by three washings for $30 \mathrm{~min}$ each in 0.1 $\mathrm{M}$ sodium cacodylate $\left(\mathrm{pH}\right.$ 6.8). ${ }^{26}$ The OBs were subjected to a secondary fixing using $1 \% \mathrm{OsO}_{4}$ plus $1.3 \% \mathrm{~K}_{3} \mathrm{Fe}(\mathrm{CN})_{6}$ for $1 \mathrm{~h}$ at room temperature. Ethanol was used to dehydrate the fixed $\mathrm{OBs}$ in increasing concentrations of 30 and $50 \% \mathrm{v} / \mathrm{v}$, for $1 \mathrm{~h}$ each followed by exposure to $70 \% \mathrm{v} / \mathrm{v}$ ethanol over $48 \mathrm{~h}$, and finally up to $100 \% \mathrm{v} / \mathrm{v}$ ethanol. Infiltration using SPURR resin (Electron Microscopy Sciences, Fort Washington, PA, USA) was instituted in a stepwise fashion proceeding from 25 to 50 to $75 \% \mathrm{v} / \mathrm{v}$ and brought up overnight to $100 \%(\mathrm{v} / \mathrm{v})$. After embedding, the material was polymerized for $48 \mathrm{~h}$ at $60{ }^{\circ} \mathrm{C}^{26}$

Cytometric Profile of Oil Bodies. OBs from G. avellana (OBs-G)

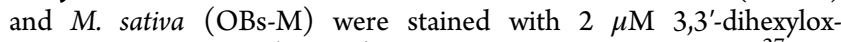
acarbocyanine iodide $\left(\mathrm{DiOC}_{6}\right)$ for $5 \mathrm{~min}$ at room temperature. ${ }^{27}$ The size and complexity of nonlabeled OBs (control) and labeled OBs were measured using a BD FACS Canto II TM flow cytometer (Becton-Dickinson, Mountain View, CA, USA) controlled by BD FACSDiva software. DiOC $_{6}$ was excited with an argon laser at $488 \mathrm{~nm}$, and emission wavelengths were measured between 520 and $550 \mathrm{~nm}$ in
FIT-C channel. The suspension circulated at a rate of $600-1000$ cells/ s, and data for 10000 OBs were collected and analyzed using the CellQuest program Pro Becton-Dickinson.

Analyses of Oil Body Neutral Lipids. Neutral lipids of OBs were extracted according to the method of Folch et al. ${ }^{28}$ after the addition of heptadecanoic acid $(\mathrm{C} 17: 0)$ as an internal standard. Lipids were saponified in $1 \mathrm{~mL}$ of $0.5 \mathrm{M} \mathrm{NaOH} / \mathrm{MeOH}$ for $10 \mathrm{~min}$ at $70{ }^{\circ} \mathrm{C}$. Then, methanolysis was performed in $1 \mathrm{~mL}$ of $\mathrm{BF}_{3} / \mathrm{MeOH}(14: 86, \mathrm{v} /$ v) for $10 \mathrm{~min}$ at $70{ }^{\circ} \mathrm{C}$. The fatty acid methyl esters (FAMEs) were extracted with pentane and analyzed by GC (7890A Agilent, Massy, France) using a split-splitless injector maintained at $250{ }^{\circ} \mathrm{C}$ and a flame ionization detector at $270{ }^{\circ} \mathrm{C}$. FAMEs were separated in a $30 \mathrm{~m}$ $\times 0.25 \mathrm{~mm}$ capillary Factor Four VF-23 ms column (Agilent). The carrier gas was helium. The column temperature program started at 40 ${ }^{\circ} \mathrm{C}$ for $1 \mathrm{~min}$, ramping to $120{ }^{\circ} \mathrm{C}$ at $40{ }^{\circ} \mathrm{C} / \mathrm{min}$, holding for $1 \mathrm{~min}$ at $120{ }^{\circ} \mathrm{C}$, ramping to $210^{\circ} \mathrm{C}$ at $3{ }^{\circ} \mathrm{C} / \mathrm{min}$, and holding for $10 \mathrm{~min}$ at $210^{\circ} \mathrm{C}$. FAME peaks were identified by comparison with commercial standards (Sigma-Aldrich) and quantified using C17:0 methyl ester as the internal standard. Results are the average of three analyses in duplicate.

Protein Quantification, Separation, and Identification by LCMS/MS. Protein quantification was carried out according to the method of Landry and Delhaye. ${ }^{29}$ Samples corresponding to $10 \mu \mathrm{g}$ of protein were diluted in a dissociation buffer consisting of $62.5 \mathrm{mM}$ Tris- $\mathrm{HCl}$ ( $\mathrm{pH} 6.8$ ), 10\% v/v glycerol, 5\% v/v 2-mercaptoethanol, $2 \%$ $\mathrm{w} / \mathrm{v}$ SDS, and $0.02 \% \mathrm{w} / \mathrm{v}$ bromophenol blue and subjected to SDSPAGE carried out according to the method of Laemmli, ${ }^{30}$ using $12 \%$ ready-to-use NuPAGE polyacrylamide gels (Novex, San Diego, CA, USA). Electrophoresis was run under $100 \mathrm{~V}$ for $180 \mathrm{~min}$ using $50 \mathrm{mM}$ MES NuPAGE buffer (pH 7.3). Gel was stained with Coomassie blue (G-250) according to the method of Neuhoff et al. ${ }^{31}$ Molecular masses were estimated with Mark 12 standard from Novex.

Protein bands stained with Coomassie blue were excised from the polyacrylamide gel and stored at $-20{ }^{\circ} \mathrm{C}$. Trypsin digestion was carried out as described by Jolivet et al. ${ }^{14}$ after reduction with $10 \mathrm{mM}$ dithiothreitol and alkylation in the dark with $55 \mathrm{mM}$ iodoacetamide. After digestion, the resulting peptides were extracted successively with formic acid $(\mathrm{HCOOH})(5 \% \mathrm{v} / \mathrm{v})$, acetonitrile/water $(50: 50, \mathrm{v} / \mathrm{v})$, and acetonitrile (ACN). Combined extracts were dried and suspended in $15 \mu \mathrm{L}$ of $0.05 \%(\mathrm{v} / \mathrm{v})$ trifluoroacetic acid, $0.05 \%(\mathrm{v} / \mathrm{v}$ ) formic acid, and $2 \%(\mathrm{v} / \mathrm{v})$ ACN. HPLC was performed with a NanoLC-Ultra Eksigent system. The sample $(4 \mu \mathrm{L})$ was loaded at a flow rate of $7.5 \mu \mathrm{L} / \mathrm{min}$ into a precolumn cartridge $(20 \mathrm{~mm}, 100 \mu \mathrm{m}$ internal diameter; stationary phase, Biosphere $\mathrm{C}_{18}, 5 \mu \mathrm{m}$; NanoSeparations, Nieuwkoop, The Netherlands) and desalted with $0.1 \%(\mathrm{v} / \mathrm{v})$ formic acid and $2 \%$ ACN. After $3 \mathrm{~min}$, the precolumn cartridge was connected to the separating column $(150 \mathrm{~mm}, 75 \mu \mathrm{m}$ internal diameter; stationary phase, Biosphere $\mathrm{C}_{18}, 3 \mu \mathrm{m}$; NanoSeparations). The buffers used were $\mathrm{H}_{2} \mathrm{O}$ (buffer A) and ACN (buffer B) each containing $0.1 \%(\mathrm{v} / \mathrm{v})$ $\mathrm{HCOOH}$. Peptides were separated using a linear gradient from 5 to $95 \% \mathrm{~B}$ for $37 \mathrm{~min}$ at $300 \mathrm{~nL} / \mathrm{min}$. A single run took $45 \mathrm{~min}$, including the regeneration step in $100 \%$ buffer B and the equilibration step in $100 \%$ buffer A. Eluted peptides were analyzed online with an LTQ XL ion trap (Thermo Electron) using a nanoelectrospray interface. Ionization $(1.5 \mathrm{kV}$ ionization potential) was achieved with a liquid junction and an uncoated capillary probe (10 $\mu \mathrm{m}$ internal diameter; New Objective, Cambridge, MA, USA). Peptide ions were analyzed using Xcalibur 2.0.7, with the following data-dependent acquisition steps: (1) full MS scan (mass-to-charge ratio $\mathrm{m} / \mathrm{z} 400-1400$, centroid mode) and (2) MS/MS (qz $=0.25$, activation time $=30 \mathrm{~ms}$, and collision energy $=35 \%$; centroid mode). Step 2 was repeated for the three major ions detected in step 1. Dynamic exclusion was set to $45 \mathrm{~s}$. $\mathrm{X}$ ! Tandem (version 2010.12.01.1; http://www.thegpm.org/tandem/) was the database search engine. Enzymatic cleavage was declared as a trypsin digestion with one possible miscleavage event. Cys carboxyamidomethylation and Met oxidation were set to static and possible modifications, respectively. Precursor mass and fragment mass tolerance were 2.0 and 0.5 , respectively. A refinement search was added with similar parameters, except that semitryptic peptide and possible N-terminal amino acid acetylation, dehydratation, or 
deamidation were searched. Searches were performed using the UniProt database restricted to spermatophyta (http://www.uniprot. org; 107,531 entries). Identified proteins were filtered and grouped using the $\mathrm{X}$ ! Tandem pipeline (http://pappso.inra.fr/bioinfo/ xtandempipeline/, version 3.1.4) according to the following specifications: (1) at least two different peptides with an $E$ value of $<0.05$ and (2) a protein $E$ value (calculated as the product of unique peptide $E$ values) of $<10^{-4}$. In the case of identification with only two or three MS/MS spectra, the similarity between the experimental and theoretical MS/MS spectra was checked visually. To take redundancy into account, proteins with at least one peptide in common were grouped. This allowed the grouping of proteins of similar function. In the absence of positive identification by sequence homology, due to the fact that $G$. avellana and $M$. sativa genomes had not been sequenced, peptide sequences were determined by de novo interpretation of MS/MS spectra using PepNovo software (version 2010225). Trypsin digestion, Cys carboxyamidomethylation, and Met oxidation were set to enzymatic cleavage, static, and possible modifications, respectively. Only sequences containing a tag of at least six amino acids with an associated probability of $>0.9$ were selected. Sequence similarity searches were performed by Fasts software (version 3.4t26) using the MD20-MS matrix. Sequences corresponding to keratins or trypsin were first removed by querying a homemade contaminant database. Second, the search computing process was carried out using the UniProt-spermatophyta database. Protein identifications were validated with a minimum of two independent peptides and an $E$ value of $<0.001$. In all cases, the automatic de novo interpretation of MS/MS spectra was confirmed visually.

Immunoblot Analyses of Oleosins. Rabbit sera anti-rS2, antirS3, and anti-rS4, raised against A. thaliana S2, S3, and S4 oleosins, were produced as described previously. ${ }^{32}$ Proteins resolved by SDSPAGE were blotted onto Immobilon-P PVDF membrane (Millipore, Molsheim, France). The membrane was probed with anti-rS2, anti-rS3, and anti-rS4 at 1:5000, 1:4000, and 1:2000 dilutions, respectively. Rabbit antibodies were revealed with peroxidase-conjugated goat antirabbit IgG from Pierce (Perbio Science, Brebières, France). Saturation and incubation with antibodies were carried out according to the method of d'Andréa et al. ${ }^{32}$ Peroxidase activity was revealed using SuperSignal West Dura Extended Duration Substrate from Pierce according to the manufacturer's protocol. Luminescence from peroxidase activity was recorded using the LAS-3000 imaging system. A MagicMark XP Western protein standard from Invitrogen was used to visualize standard bands.

Effect of pH and lonic Strength on the Stability of Oil Body Suspensions. The influence of $\mathrm{pH}$ and ionic strength on the stability of OBs from G. avellana and M. sativa was examined by means of the turbidity test. ${ }^{33}$ The $600 \mathrm{~nm}$ absorbance of the suspension in the lower portion of the cuvette was measured at $18{ }^{\circ} \mathrm{C}$ and time intervals (Optizen 3220 UV spectrophotometer). The oil suspension was diluted 5-fold in Tris- $\mathrm{HCl}$ buffer at known $\mathrm{pH}$ ( $\mathrm{pH}$ 5.5-9.5) or $\mathrm{NaCl}$ concentration $(0-150 \mathrm{mM})$.

The turbidity $(T)$ of the suspension was proportional to $10^{A}$, and the relative turbidity was expressed at $T / T_{0}=10^{A} / 10^{A_{0}}$. Rate constants of relative turbidity variation (or stability constant, $K_{\mathrm{st}}$ ) were calculated using a first-order kinetic model that assumed a decrease of the turbidity over time. Results were submitted to analysis of variance (ANOVA) followed by Duncan's test of multiple comparisons. The significance was determined at a 5\% confidence level. All of the results are presented as the average value \pm standard deviation of three replicates.

Cytotoxicity Effect of Oil Bodies on Human Umbilical Venous Endothelial Cells (HUVEC). HUVEC (from the umbilical cords of newborns) were isolated according to the method of Jaffe et $\mathrm{al}^{34}$ and grown in dish plates $(10 \mathrm{~cm})$. The culture medium was M199 modified supplemented with horse serum (10\%), bovine fetal serum $(10 \%)$, and a mixture of penicillin-streptomycin $(10000 \mathrm{U} / \mathrm{mL})$. All cells were maintained at $37{ }^{\circ} \mathrm{C}$ in a humidified incubator at $5 \% \mathrm{CO}_{2}$. The HUVEC were incubated with $2 \mathrm{mg} / \mathrm{mL}$ of OB suspension for $3 \mathrm{~h}$. Finally, the viability of cells was estimated by trypan blue (trypan blue stain, Sigma-Aldrich, Steinheim, Germany) exclusion staining $0.4 \%$ v/ $\mathrm{v}$. The colorimetric change determined through optical microscopy is an index of total nonviable cells labeled with the dye and visible with bright-field optics. ${ }^{35}$

\section{RESULTS AND DISCUSSION}

Oil Bodies Extraction and Droplet Shape. Lipid contents measured by Soxhlet extraction were $30 \%$ in G. avellana seeds and $20 \%$ in $M$. sativa seeds. The fatty acid/total protein ratio was close to 2.6 and 0.7 in the mature seeds of $G$. avellana and $M$. sativa, respectively, taking into account protein content (11.5 and $29 \% \mathrm{w} / \mathrm{w}$, respectively). In typical OB preparations with $1 \mathrm{~g}$ of fresh weight of desiccated mature seeds as starting material, $1.9 \mathrm{mg}$ of proteins and $54.3 \mathrm{mg}$ of fatty acid in TAG for G. avellana and $1.4 \mathrm{mg}$ of proteins and $41.2 \mathrm{mg}$ of fatty acid for $M$. sativa were obtained. The fatty acid/protein ratio in OBs was near 29 for the two seeds, indicating high lipid enrichment. The extraction yield of OB was 18.3 and $20.5 \%$ for G. avellana and M. sativa, respectively. This extraction yield is similar with that obtained by Iwanaga et al. ${ }^{3}$ from soybeans.

OBs were observed by optical and confocal microscopy and TEM analysis. As shown in Figure 1, OBs were selectively

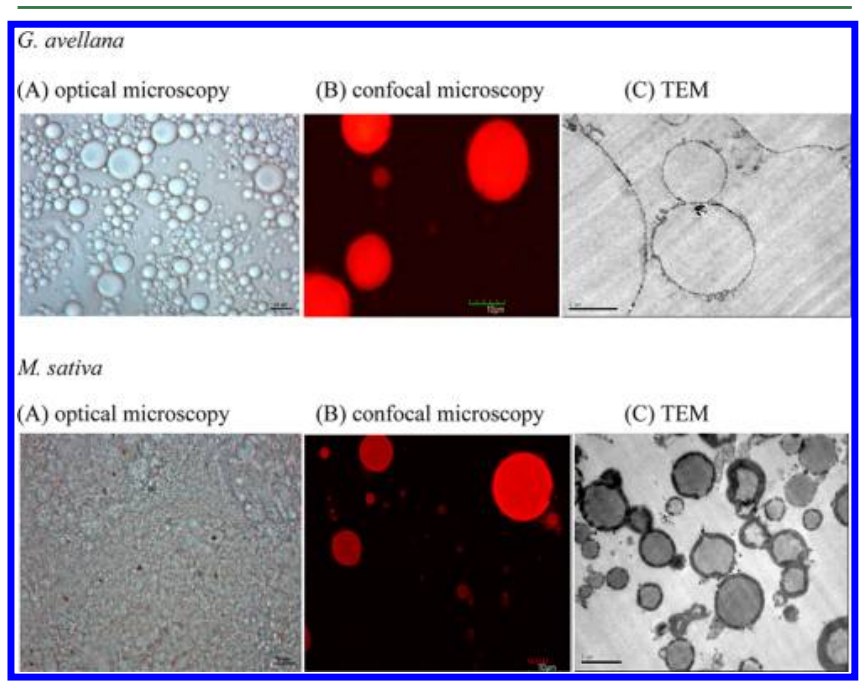

Figure 1. Microphotographs of oil bodies from G. avellana and $M$. sativa by optical microscopy $(\times 100$, oil immersion) (A), confocal microscopy (B), and TEM (C).

stained by Nile red (a neutral lipid stain). The microscopic analysis revealed a spherical shape of G. avellana and $M$. sativa OBs; however, some differences were observed depending on the source. In fact, OBs-M seem to be surrounded by a thicker coat than the OBs-G.

Cytometric Profile of Oil Bodies. Flow cytometric analysis was used as a complementary tool for the characterization of OBs. ${ }^{35}$ To our knowledge this is the first time that this technique has been used for this purpose. By means of this analysis the complexity and size of OBs- $\mathrm{G}$ and OBs-M in a high cell number (10000) were evaluated. Cytometric profiles of OBs according to (i) size and complexity (dot plot), (ii) intensity of basal fluorescence (histogram), (iii) size and complexity of $\mathrm{OBs}$ stained with $\mathrm{DiOC}_{6}$ (dot plot), and (iv) intensity of fluorescence of OBs stained with $\mathrm{DiOC}_{6}$ (histogram) were obtained (Figure 2). $\mathrm{DiOC}_{6}$, a lipophilic fluorescent stain for labeling membranes and other hydrophobic structures, is a positively charged (cationic) carbocyanine dye that binds readily to negatively charged cells. ${ }^{36}$ Once 
(A) Gevuina avellana

(i)

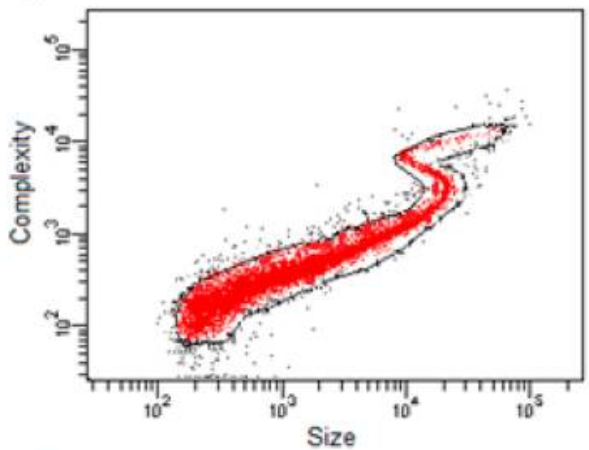

(iii)

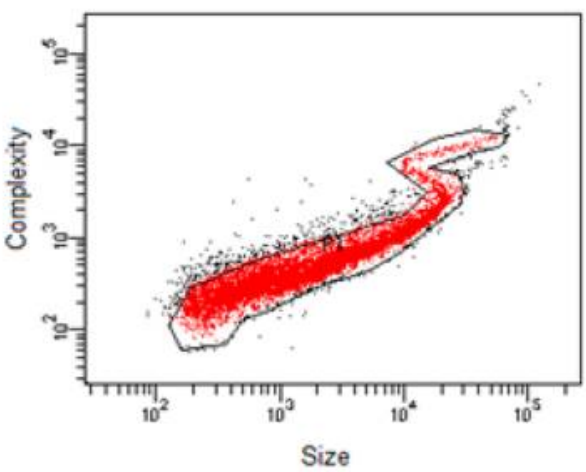

(B) Madia sativa

(i)

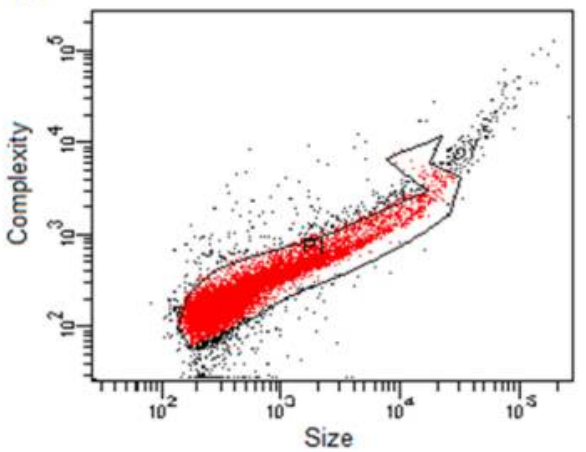

(iii)

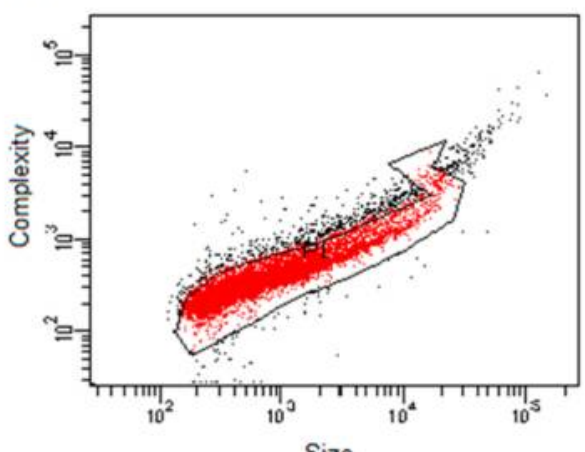

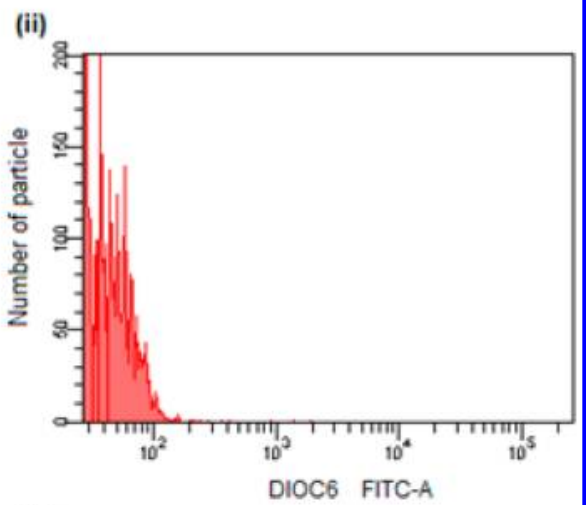

(iv)

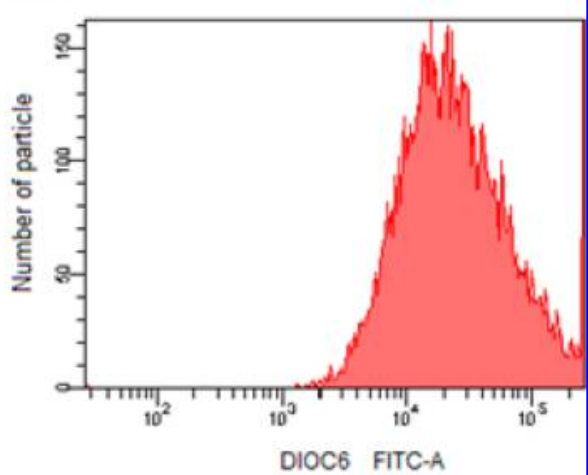

(ii)

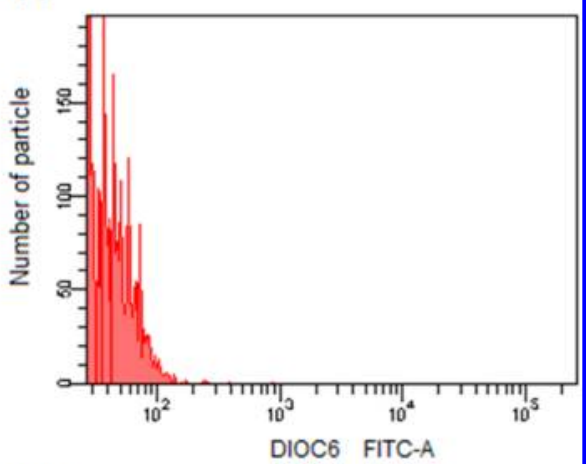

(iv)

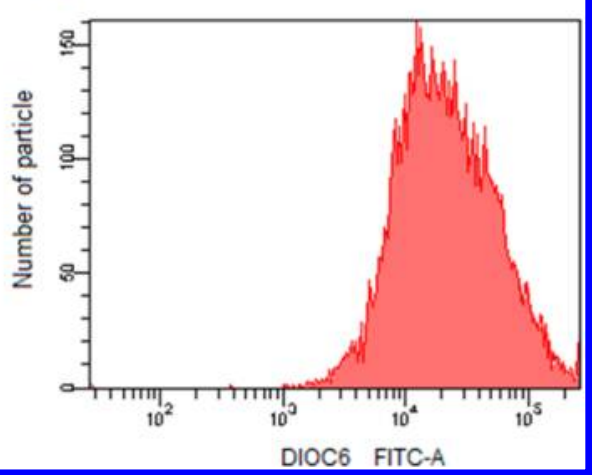

Figure 2. Representative cytometric profiles of oil bodies from G. avellana (A) and M. sativa (B), according to (i) size and complexity (dot plot), (ii) intensity of basal fluorescence (histogram), (iii) size and complexity with $\mathrm{DiOC}_{6}$ (dot plot), and (iv) intensity of fluorescence with $\mathrm{DiOC}_{6}$ (histogram). 
applied to $\mathrm{OBs}, \mathrm{DiOC}_{6}$ diffused within $\mathrm{OB}$, resulting in a complete staining (data not shown). As shown in Figure 2, OBs-G and OBs-M presented similar cytometric profiles regarding the size, complexity, and staining with $\mathrm{DiOC}_{6}$. However, the dot plots obtained indicate that OBs-M showed a size and complexity lower than those presented in OBs-G. The mean of fluorescence intensity for the control OBs population and that labeled with $\mathrm{DiOC}_{6}$ were 7 and 25.583 for OBs-G, respectively; in the case of $M$. sativa, the values were 8 and 12.770 , respectively. The higher fluorescence intensity in OBs$\mathrm{G}$ can be attributed to a major size and complexity presented in the population analyzed. These results indicate that the staining technique for both OBs using $\mathrm{DiOC}_{6}$ was appropriate, and the flow cytometry analysis performed in this study constitutes a rapid and simple method for the characterization of OBs. As oil bodies are considered to be natural equivalents of liposomes and natural oil-in-water emulsions, we estimate that the data of size, complexity, and fluorescence intensity of OBs-G and OBs$\mathrm{M}$ determined by flow cytometry and represented in dot plot and histograms in this study are valid parameters for the characterization and comparison of oil bodies extracted from different seeds.

Fatty Acids of Oil Bodies. Fatty acids of neutral lipids extracted from the OBs-G were highly monounsaturated $(84.3 \%)$, containing mainly oleic acid $(25.5 \%)$ and an uncommon monoenoic fatty acid, 16:1(n-5) (26.4\%) (Table $1)$; minor amounts of saturated fatty acids (5\%) and

Table 1. GC Analyses of TAGs from Gevuina avellana and Madia sativa Oil Bodies

\begin{tabular}{|c|c|c|c|c|}
\hline \multirow[b]{3}{*}{$\begin{array}{l}\text { fatty acid } \\
\text { composition }\end{array}$} & \multicolumn{4}{|c|}{ total fatty acids (\%) } \\
\hline & \multicolumn{2}{|c|}{ G. avellana } & \multicolumn{2}{|c|}{ M. sativa } \\
\hline & $\begin{array}{l}\text { this work } \\
(\mathrm{SD})^{a}\end{array}$ & $\begin{array}{c}\text { Bertoli et } \\
\text { al. } \\
(1988)\end{array}$ & $\begin{array}{l}\text { this work } \\
(\mathrm{SD})^{a}\end{array}$ & $\begin{array}{l}\text { Schmeda- } \\
\text { Hirschmann } \\
\text { (1995) }\end{array}$ \\
\hline $16: 0$ & $1.60(0.004)$ & 1.9 & $13.25(0.096)$ & 13.45 \\
\hline $16: 1(n-5)$ & $26.36(0.046)$ & 22.7 & & \\
\hline $18: 0$ & $0.39(0.002)$ & 0.5 & $3.63(0.027)$ & 3.85 \\
\hline $18: 1(n-9)$ & $25.52(0.060)$ & 39.4 & $9.30(0.064)$ & 9.05 \\
\hline $18: 1(n-5)$ & $9.36(0.021)$ & & & \\
\hline $18: 1(n-6)$ & & 6.2 & & \\
\hline $18: 2(n-6)$ & $10.00(0.023)$ & 5.6 & $69.73(0.368)$ & 71.9 \\
\hline $18: 3(n-3)$ & $0.12(0.002)$ & 0.1 & $0.20(0.004)$ & \\
\hline $20: 0$ & $1.01(0.003)$ & 1.4 & $0.52(0.004)$ & 0.8 \\
\hline $20: 1(n-9)$ & $1.83(0.009)$ & 3.1 & & \\
\hline $20: 1(n-5)$ & $9.14(0.017)$ & 6.6 & & \\
\hline $22: 0$ & $1.62(0.008)$ & 2.2 & & \\
\hline $22: 1(n-9)$ & $1.00(0.006)$ & & & \\
\hline $22: 1(n-3)$ & & 1.6 & & \\
\hline $22: 1(n-5)$ & $11.09(0.030)$ & 7.9 & & \\
\hline $24: 0$ & $0.38(0.006)$ & 0.5 & & \\
\hline
\end{tabular}

polyunsaturated fatty acids (10.1\%) such as linoleic acid (10\%) and $\alpha$-linolenic acid $(0.1 \%)$ were also detected. By contrast, OBs-M contained mainly polyunsaturated fatty acids (69.9\%) such as linoleic acid (69.7\%) and $\alpha$-linolenic acid $(0.2 \%)$ and lower amounts of oleic acid $(9.3 \%)$ and of saturated fatty acids such as palmitic acid (13.2\%), stearic acid (3.6\%), eicosanoic acid (0.5\%), and oleic acid (9.3\%).

The fatty acid profile of the lipids from OBs-G is in good agreement with that reported by Bertoli et al. ${ }^{21}$ for G. avellana oil except that these authors observed higher oleic acid content (Table 1). In our experiments, we logically identified two positional isomers corresponding to the $n-9$ and $n-5$ family for each monounsaturated fatty acid. Bertoli et al. ${ }^{21}$ mentioned the presence of two other minor fatty acids $\left(\mathrm{C}_{18: 1(\mathrm{n}-6)}\right.$ and $\left.\mathrm{C}_{22: 1(\mathrm{n}-3)}\right)$ we did not identify. G. avellana oil contains $56 \%$ of monounsaturated fatty acids of the n-5 family. These unusual fatty acid positional isomers are not widely found in plants but have been also mentioned in Grevillea robusta, another Proteaceae known as the silk oak, an Australian shade and timber tree. ${ }^{37}$ These authors found the $n-5$ monoene series with chain lengths of $\mathrm{C}_{14}-\mathrm{C}_{28}$ and comprising $22.5 \%$ of the fatty acids derived from the seed oil of this plant. The concentrations of some $\mathrm{n}-5$ isomers occurred in higher concentration in other Proteaceae. ${ }^{38,39}$ The fatty acid pattern of OBs-M was similar to that reported in seeds by SchmedaHirschmann. ${ }^{22}$

Effect of $\mathrm{pH}$ and lonic Strength on the Stability of Oil Body Suspensions. It is known that OBs are remarkably stable either inside the cells or in isolated preparation ${ }^{32}$ at neutral $\mathrm{pH}$. ${ }^{4}$ However, the stability could change depending on the $\mathrm{pH}$ and ionic strength. For example, under acidic conditions histidine residues may be protonated resulting in the neutralization of the OB surface. ${ }^{40}$ In addition, monovalent cations $\left(\mathrm{Na}^{+}\right)$may partially displace divalent cations such as $\mathrm{Mg}^{2+}$ or $\mathrm{Ca}^{2+}$ associated with the anionic OB surface at neutral $\mathrm{pH}$, thereby counterbalancing the expected decrease in negative charge. ${ }^{3}$

An indirect stability measurement of the OBs extracted from $G$. avellana and $M$. sativa seeds was determined as a function of $\mathrm{pH}$ and ionic strength. As shown in Table 2, the $\mathrm{pH}$ did not

Table 2. Stability Constants $\left(K_{\text {st }}\right)$ under Variable Conditions of $\mathrm{pH}$ and Ionic Strength ${ }^{a}$

\begin{tabular}{|c|c|c|}
\hline \multirow[b]{2}{*}{ (A) $\mathrm{pH}$} & \multicolumn{2}{|c|}{ stability constant $\left(K_{\text {st }}\right)$} \\
\hline & G. avellana & M. sativa \\
\hline 5.5 & $10.90 \times 10^{-2} \pm 0.0028 \mathrm{a}$ & $5.65 \times 10^{-2} \pm 0.0007 \mathrm{~b}$ \\
\hline 6.5 & $15.60 \times 10^{-2} \pm 0.0226 \mathrm{a}$ & $9.15 \times 10^{-2} \pm 0.0160 \mathrm{~b}$ \\
\hline 7.5 & $12.70 \times 10^{-2} \pm 0.0085 \mathrm{a}$ & $9.40 \times 10^{-2} \pm 0.0141 \mathrm{~b}$ \\
\hline 8.5 & $12.45 \times 10^{-2} \pm 0.0129 \mathrm{a}$ & $8.15 \times 10^{-2} \pm 0.0260 \mathrm{~b}$ \\
\hline 9.5 & $11.95 \times 10^{-2} \pm 0.0233 \mathrm{a}$ & $5.90 \times 10^{-2} \pm 0.0010 \mathrm{~b}$ \\
\hline \multirow[b]{2}{*}{ (B) $\mathrm{NaCl}(\mathrm{mM})$} & \multicolumn{2}{|c|}{ stability constant $\left(K_{\mathrm{st}}\right)$} \\
\hline & G. avellana & M. sativa \\
\hline 0 & $10.25 \times 10^{-2} \pm 0.0160 \mathrm{a}$ & $6.80 \times 10^{-2} \pm 0.0028 \mathrm{~b}$ \\
\hline 10 & $10.80 \times 10^{-2} \pm 0.0042 \mathrm{a}$ & $5.35 \times 10^{-2} \pm 0.0021 \mathrm{~b}$ \\
\hline 50 & $11.65 \times 10^{-2} \pm 0.0021 \mathrm{a}$ & $7.70 \times 10^{-2} \pm 0.0300 \mathrm{~b}$ \\
\hline 100 & $9.20 \times 10^{-2} \pm 0.0057 \mathrm{a}$ & $8.20 \times 10^{-2} \pm 0.0028 \mathrm{~b}$ \\
\hline 150 & $11.75 \times 10^{-2} \pm 0.0050 \mathrm{a}$ & $7.35 \times 10^{-2} \pm 0.0190 \mathrm{~b}$ \\
\hline
\end{tabular}

${ }^{a}$ Different letters indicate significant differences between means of $K_{\text {st }}$ at different $\mathrm{pH}$ values, according to analysis of variance (ANOVA) followed by Duncan's test of multiple comparisons at 0.05 significance.

influence $(p>0.05)$ the stability of either OB in the $\mathrm{pH}$ range from 5.5 to 9.5 . However, the stability of the OBs from $M$. sativa differed significantly from that of $G$. avellana OBs $(p<$ 0.05 ); OBs-M have a stronger electrostatic repulsion (lower $K_{\mathrm{st}}$ values) that prevents them from aggregating and coalescing compared to OBs-G (Table 2; Figure 3).

With regard to the $\mathrm{NaCl}$ effect, no significant differences $(p>$ 0.05 ) were observed in the stability of the OBs from $M$. sativa and G. avellana for salt concentration in the range between 0 

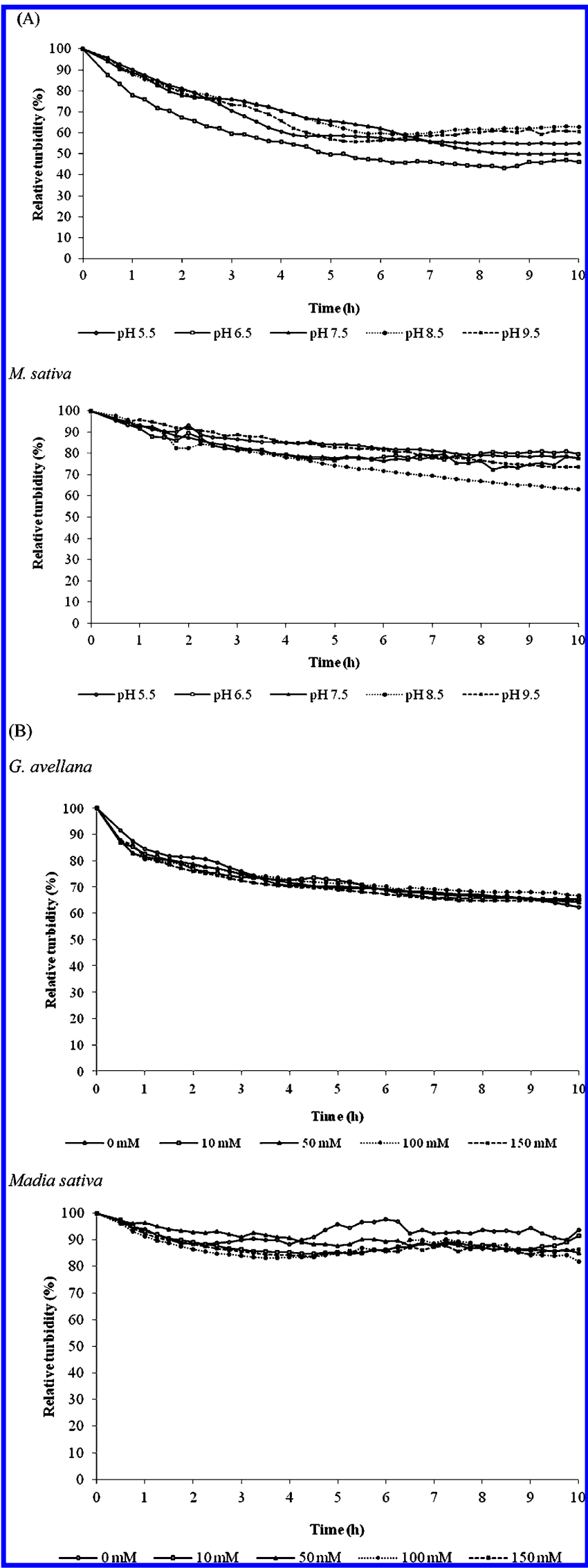

Figure 3. Stability of oil bodies from G. avellana and M. sativa under variable conditions of $\mathrm{pH}(\mathrm{A})$ and ionic strength (B). and $150 \mathrm{mM}$. Furthermore, the results indicate that the suspensions of OBs have a high stability to aggregation and coalescence in the presence of $\mathrm{NaCl}$. Under these conditions, OBs-M showed stronger electrostatic repulsion (lower $K_{\text {st }}$ values) in comparison to the behavior of OBs-M in the presence of $\mathrm{NaCl}$ (Table 2; Figure 3).

This indirect stability measurement is a helpful parameter; however, it does not consider the interaction of ions with proteins and lipid surfaces, an immensely complicated area that is not fully understood.

As oleosins are known to play an important role in the stability of OBs exposing negatively charged residues to the cytosol, thereby providing the electronegative repulsion force needed for preventing aggregation and coalescence, ${ }^{41}$ we performed an exhaustive identification of the proteins associated with OBs-G and OBs-M.

Identification of OB Proteins by LC-MS/MS. Proteins from the suspensions of OBs were analyzed by SDS-PAGE in denaturing conditions (Figure 4). Rather simple patterns were

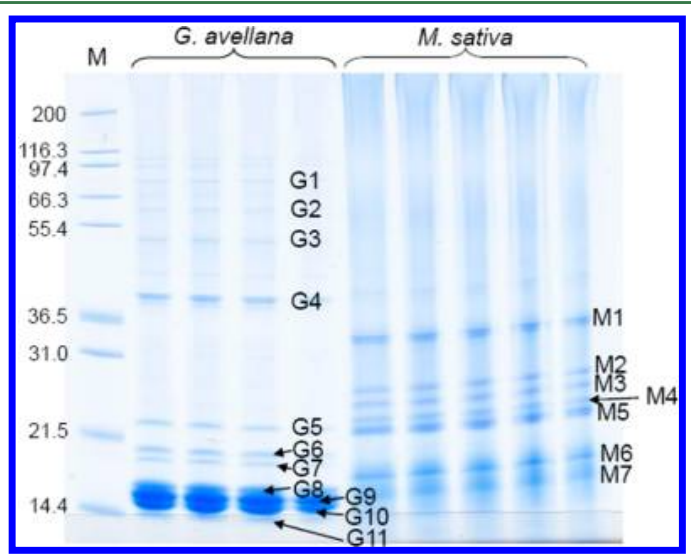

Figure 4. SDS-PAGE of proteins from isolated oil bodies from $G$. avellana and $M$. sativa seeds (10 $\mu \mathrm{g}$ protein/lane). Molecular mass marker (M) was Mark 12 from Novex. Coomassie-blue stained protein bands were numbered as listed in Tables 3 and 4 and in the Supporting Information.

obtained with a limited number of protein bands between 14 and $100 \mathrm{kDa}$. However, the patterns corresponding to the two seeds were very different. All of the bands were excised and subjected to trypsin proteolysis, and the resulting peptides were analyzed by MS. As the genomes of G. avellana and M. sativa are not sequenced, protein identification was performed by sequence homology against a large database restricted to spermatophyta. On a second run, a new query using PepNovo software was realized with the mass spectra not used for the first identification. The results are presented in Tables 3 and 4 and as Supporting Information. Despite the complementary study performed with the two pieces of software, only a few proteins were identified, especially for OBs-M. In particular, it was not possible to obtain information about the low molecular weight proteins, the most abundant according to the intensity of the Coomassie staining. A total of 40 proteins were identified from OBs-G and 23 from M. sativa OBs-M. For each protein, the name and the putative molecular function of the protein displaying the best sequence homology were reported. Clearly, the two OBs proteomes strongly differed.

Some ribosomal proteins were associated with OBs-M, but their abundance was low due to the fact that they were identified with few mass spectra (Table 3). OB preparation 
Table 3. Proteins Identified in OBs Purified from M. sativa $a^{a}$

\begin{tabular}{|c|c|c|c|c|c|c|}
\hline $\begin{array}{l}\text { protein band (observed } \\
\mathrm{MW}, \mathrm{kDa})\end{array}$ & protein identification $^{b}$ & $\begin{array}{l}\text { entry name in UniProt database } e^{c} \\
(\text { accession no. })^{d}\end{array}$ & $\begin{array}{l}\text { supposed molecular } \\
\text { function }\end{array}$ & $\log (E$ value $)$ & $\begin{array}{l}\underset{(\mathrm{kDa})}{\operatorname{mean} \mathrm{MW}^{f}} \\
\end{array}$ & $\begin{array}{c}\text { mass } \\
\text { spectra no. }\end{array}$ \\
\hline \multirow[t]{3}{*}{ M1 (33 kDa) } & prohibitin & Q5ECI7_PETHY & $\begin{array}{l}\text { mitochondrial } \\
\text { prohibitin }\end{array}$ & -11.324574 & 32 & 7 \\
\hline & 40S ribosomal protein S3 & RS33_ARATH (Q9FJA6) & $\begin{array}{l}\text { ribosomal protein, } \\
\text { RNA binding }\end{array}$ & -5.514278 & 27 & 2 \\
\hline & $\begin{array}{l}11 S \text { globulin seed storage } \\
\text { protein }^{\text {g }}\end{array}$ & 11S3_HELAN (P19084) & seed storage protein & -4.494850 & 56 & 21 \\
\hline M2 (26 kDa) & Ras-related protein RABAle & RAA1E_ARATH (O49513) & $\begin{array}{l}\text { protein transport, GTP } \\
\text { binding }\end{array}$ & -4.348722 & 24 & 3 \\
\hline \multirow[t]{5}{*}{ M3 (24 kDa) } & Ras-related protein RABG3 & RAG3D_ARATH (Q9C820) & $\begin{array}{l}\text { protein transport, GTP } \\
\text { binding }\end{array}$ & -9.733233 & 24 & 8 \\
\hline & Ras-related protein Rab 11 & B4F7 V4_MAIZE & $\begin{array}{l}\text { protein transport, GTP } \\
\text { binding }\end{array}$ & -11.862392 & 24 & 5 \\
\hline & Ras-related protein $\mathrm{RABC}$ & A5ATB8_VITVI & $\begin{array}{l}\text { protein transport, GTP } \\
\text { binding }\end{array}$ & -13.176786 & 23 & 4 \\
\hline & $\begin{array}{l}\text { allergen } 11 S \text { seed storage } \\
\text { globulin precusor }\end{array}$ & B7P073_PISVE & seed storage protein & -7.517698 & 56 & 6 \\
\hline & $40 \mathrm{~S}$ ribosomal protein $\mathrm{S} 5$ & B9T025_RICCO & $\begin{array}{l}\text { ribosomal protein, } \\
\text { RNA binding }\end{array}$ & -7.522879 & 23 & 4 \\
\hline \multirow[t]{7}{*}{ M4 (23 kDa) } & avenin & AVEN_AVESA (P27919) & seed storage protein & -11.289208 & 24 & 6 \\
\hline & GTP-binding protein SAR & Q8VYP7_ARATH & $\begin{array}{l}\text { ER-Golgi transport, } \\
\text { GTP binding }\end{array}$ & -7.617479 & 22 & 4 \\
\hline & $\begin{array}{l}\text { Rab-related small GTP- } \\
\text { binding protein }\end{array}$ & Q84RR9_SIMCH & $\begin{array}{l}\text { protein transport, GTP } \\
\text { binding }\end{array}$ & -7.99140 & 22 & 3 \\
\hline & Ras-related protein $\mathrm{RABD} 2 \mathrm{~b}$ & RAD2B (Q9FPJ4) & $\begin{array}{l}\text { ER-Golgi transport, } \\
\text { GTP binding }\end{array}$ & -11.088949 & 22 & 3 \\
\hline & aquaporin TIP3-2 & TIP32_ARATH (O22588) & water transport & -11.631342 & 28 & 3 \\
\hline & $60 S$ ribosomal protein $\mathrm{L} 18$ & B9SAT7_RICCO & ribosomal protein & -7.378824 & 21 & 2 \\
\hline & $40 S$ ribosomal protein $S 18$ & B9S400_RICCO & $\begin{array}{l}\text { ribosomal protein, } \\
\text { RNA binding }\end{array}$ & -4.206908 & 17 & 2 \\
\hline \multirow[t]{5}{*}{ M5 (22 kDa) } & $\begin{array}{l}11 \mathrm{~S} \text { globulin seed storage } \\
\text { protein }\end{array}$ & 11S3_HELAN (P19084) & seed storage protein & -22.051775 & 55 & 12 \\
\hline & $\begin{array}{l}\text { glyceraldehyde-3-phosphate } \\
\text { dehydrogenase }\end{array}$ & D9IE12_THYVU & oxidoreductase & -10.253366 & 19 & 4 \\
\hline & $60 S$ ribosomal protein L11 & RL11_ORYSI (A2YDY2) & $\begin{array}{l}\text { ribosomal protein, } \\
\text { rRNA binding }\end{array}$ & -13.768938 & 21 & 5 \\
\hline & $60 S$ ribosomal protein $\mathrm{L} 12$ & B4FRM7_MAIZE & ribosomal protein & -9.154902 & 18 & 3 \\
\hline & $40 S$ ribosomal protein $S 15$ & B9RTE6_RICCO & $\begin{array}{l}\text { ribosomal protein, } \\
\text { RNA binding }\end{array}$ & -6.405276 & 17 & 2 \\
\hline M6 (18 kDa) & $40 S$ ribosomal protein $\mathrm{S} 16$ & B5KV60_HELAN & ribosomal protein & -7.420217 & 15 & 2 \\
\hline M7 (16 kDa) & 60 S ribosomal protein $\mathrm{L} 14$ & B9SV21_RICCO & ribosomal protein & -7.097997 & 15 & 3 \\
\hline
\end{tabular}

${ }^{a}$ Band number refers to bands in Figure $4 .{ }^{b}$ Protein identification was performed using X!Tandem and sequence homology in the UniProt database restricted to spermatophyta. ${ }^{c}$ Entry name in UniProt database of the protein displaying the best sequence homology. ${ }^{d}$ Accession number in SwissProt if one exists. ${ }^{e}$ Possible function reported by UniProt/Swiss-Prot. ${ }^{f}$ Mean molecular mass calculated from all proteins grouped by a similar function as explained under Materials and Methods. ${ }^{g}$ Proteins in italics were identified using PepNovo software.

using alkaline conditions is able to mimic and simplify the laborious purification method of Tzen et al. ${ }^{41}$ but a contrario may favor the recovery of very basic ribosomal proteins. The most abundant proteins were homologous to avenin and to $11 \mathrm{~S}$ globulin belonging to the storage protein family and indicating a low contamination of $\mathrm{OB}$ fraction with protein bodies, which has been reported elsewhere. ${ }^{18,19}$ Other largely identified proteins were Ras-related proteins involved in the protein transport between the endoplasmic reticulum and the Golgi apparatus. The presence of these proteins involved in membrane traffic has been reported in mammalian and microbial lipid droplets. ${ }^{42,43}$ Finally, the unique protein clearly identified as closely associated with seed OBs was aquaporin, belonging to the tonoplast intrinsic protein (TIP) family. ${ }^{14,15}$ TIP aquaporins are classically water facilitators, but they can also present glycerol transport activity. ${ }^{44}$

Proteins involved in storage accumulation, protein biosynthesis (ribosomal proteins and elongation factor), and protein transport were less present in OBs-G (Table 4). Among the most abundant proteins, three belong to cytoskeleton and are involved in intracellular trafficking (actin, $\alpha$ and $\beta$ tubulin). Several proteins are chaperone or stimuli-induced proteins, such as indole-3-acetic acid-amido synthetase or jasmonate inducible protein. Two proteins are involved in protein degradation process (polyubiquitin and 26S proteasome regulatory subunit). Contrary to the case of OBs-M, numerous 
Table 4. Proteins Identified in OBs Purified from G. avellana ${ }^{a}$

\begin{tabular}{|c|c|c|c|c|c|c|}
\hline $\begin{array}{l}\text { protein band } \\
\text { (observed MW, } \\
\text { kDa) }\end{array}$ & protein identification $^{b}$ & $\begin{array}{c}\text { entry name in UniProt } \\
\text { database }^{c}(\text { accession no. })^{d}\end{array}$ & supposed molecular function ${ }^{e}$ & $\log (E$ value $)$ & $\begin{array}{l}\text { mean } \\
\mathrm{MW}^{f} \\
(\mathrm{kDa})\end{array}$ & $\begin{array}{c}\text { mass } \\
\text { spectra } \\
\text { no. }\end{array}$ \\
\hline \multirow[t]{10}{*}{ G1 $(81 \mathrm{kDa})$} & calnexin homologue & CALX_SOYBN (Q39817) & $\begin{array}{l}\text { chaperone, protein folding, } \\
\text { calcium ion binding }\end{array}$ & -14.698536 & 61 & 9 \\
\hline & heat shock protein 60 & D7TS57_VITVI & $\begin{array}{l}\text { chaperone, protein refolding, } \\
\text { ATP binding }\end{array}$ & -23.934792 & 60 & 8 \\
\hline & malate synthase & MASY_GOSHI (P17432) & acyltransferase & -9.662341 & 64 & 7 \\
\hline & $\begin{array}{l}\text { putative uncharacterized protein, } \\
\text { DEAD box helicase family }\end{array}$ & A5BI23_VITVI & $\begin{array}{l}\text { ATP-dependent helicase } \\
\text { activity }\end{array}$ & -20.697400 & 46 & 7 \\
\hline & putative uncharacterized protein & C5Z6P5_SORBI & $\begin{array}{l}\text { proton transport, inorganic } \\
\text { diphosphatase activity }\end{array}$ & -21.991360 & 80 & 6 \\
\hline & $\begin{array}{l}\text { putative uncharacterized protein, } \\
\text { TCP chaperonin family }\end{array}$ & A5C537_VITVI & $\begin{array}{l}\text { chaperonin family, ATP } \\
\text { binding }\end{array}$ & -9.347947 & 63 & 3 \\
\hline & $\begin{array}{l}\text { putative uncharacterized protein, } \\
\text { TPP enzyme family }\end{array}$ & A2WKY8_ORYSI & $\begin{array}{l}\text { carboxy-lyase activity, thiamin } \\
\text { pyrophosphate binding }\end{array}$ & -5.142668 & 64 & 2 \\
\hline & putative uncharacterized protein & D7SYK8_VITVI & ATP citrate synthase activity & -8.014125 & 66 & 2 \\
\hline & $\begin{array}{l}\text { indole-3-acetic acid-amido } \\
\text { synthetase }\end{array}$ & GH32_ARATH (Q9SZT9) & $\begin{array}{l}\text { ligase, response to auxin } \\
\text { stimulus }\end{array}$ & -4.800245 & 62 & 2 \\
\hline & putative uncharacterized $^{g}$ & D7TYA2_VITVI & glycerone kinase activity & -9.337242 & 62 & 12 \\
\hline \multirow[t]{7}{*}{$\mathrm{G} 2(61 \mathrm{kDa})$} & elongation factor $1-\alpha$ & Q3LUM2_GOSHI & $\begin{array}{l}\text { protein biosynthesis, GTPase } \\
\text { activity }\end{array}$ & -36.939730 & 49 & 19 \\
\hline & tubulin $\beta$ chain & TBB6_ARATH (P29514) & microtubule, GTP binding & -23.678587 & 50 & 13 \\
\hline & tubulin $\alpha$ chain & TBA6_MAIZE (P33627) & microtubule, GTP binding & -14.894074 & 50 & 8 \\
\hline & $\begin{array}{l}\text { succinate semialdehyde } \\
\text { dehydrogenase }\end{array}$ & B6TPI6_MAIZE & oxidoreductase & -28.181347 & 56 & 12 \\
\hline & $\begin{array}{l}\text { 6-phosphogluconate } \\
\text { dehydrogenase, decarboxylating }\end{array}$ & COPL33_MAIZE & oxidoreductase, pentose shunt & -20.387102 & 53 & 10 \\
\hline & adenosylhomocysteinase & $\begin{array}{l}\text { SAHH2 ARATH } \\
(\text { Q9LK36) }\end{array}$ & hydrolase, methylation control & -9.233361 & 53 & 4 \\
\hline & $\beta$-glucosidase & BGL23_ARATH (Q9SR37) & $\begin{array}{l}\beta \text {-glucosidase, carbohydrate } \\
\text { metabolism process }\end{array}$ & -8.782517 & 60 & 2 \\
\hline \multirow[t]{8}{*}{$\mathrm{G} 3(50 \mathrm{kDa})$} & actin & A5BN09_VITVI & ATP binding & -65.784770 & 42 & 39 \\
\hline & phosphoglycerate kinase & A5CAF6_VITVI & $\begin{array}{l}\text { phosphoglycerate kinase, } \\
\text { glycolysis }\end{array}$ & -7.856361 & 50 & 5 \\
\hline & predicted protein, ATPase family & A9PB39_POPTR & $\begin{array}{l}\text { nucleoside triphosphatase } \\
\text { activity }\end{array}$ & -12.934329 & 45 & 4 \\
\hline & alcohol dehydrogenase & O82478_SOYBN & oxidoreductase & -4.951558 & 40 & 3 \\
\hline & $\begin{array}{l}26 \mathrm{~S} \text { proteasome non-ATPase } \\
\text { regulatory subunit }\end{array}$ & $\begin{array}{l}\text { PSMD6_ARATH } \\
(\mathrm{Q} 93 \mathrm{Y3} 5)\end{array}$ & $\begin{array}{l}\text { involved in the degradation of } \\
\text { ubiquitinated proteins }\end{array}$ & -8.765483 & 44 & 2 \\
\hline & $\begin{array}{l}\text { chloroplast inner envelope } \\
\text { membrane protein }\end{array}$ & IN37_SPIOL (P23525) & methyltransferase activity & -8.061481 & 39 & 2 \\
\hline & GTP-binding protein & B4FUE0_MAIZE & GTP binding & -5.055517 & 44 & 2 \\
\hline & $\begin{array}{l}\text { strictosidine synthase family } \\
\text { protein }\end{array}$ & D7M0S8_ARALL & strictosidine synthase activity & -8.958608 & 44 & 2 \\
\hline \multirow[t]{3}{*}{$\mathrm{G} 4(40 \mathrm{kDa})$} & corticosteroid 11- $\beta$-dehydrogenase & B9SPX3_RICCO & oxidoreductase & -19.161781 & 40 & 24 \\
\hline & adenosine kinase & C6T7F3_SOYBN & adenosine kinase activity & -8.086186 & 37 & 3 \\
\hline & putative uncharacterized protein & D7THA1_VITVI & unknown function & -11.815649 & 35 & 3 \\
\hline \multirow[t]{7}{*}{ G5 (23 kDa) } & polyubiquitin & UBQ8_ARATH (Q39256) & ubiquitin conjugation & -27.797846 & 28 & 14 \\
\hline & Ras-related protein & RAD2A_ARATH (P28188) & $\begin{array}{l}\text { ER-Golgi transport, GTP } \\
\text { binding }\end{array}$ & -14.315298 & 23 & 5 \\
\hline & small GTPase/SAR family protein & D7U2H1_VITVI & $\begin{array}{l}\text { ER-Golgi transport, GTP } \\
\text { binding }\end{array}$ & -10.982425 & 22 & 4 \\
\hline & $60 S$ ribosomal protein L11 & RL112_ARATH (P42794) & tRNA binding & -13.949543 & 21 & 3 \\
\hline & $40 S$ ribosomal protein S5 & B9T025_RICCO & RNA binding & -12.917358 & 23 & 3 \\
\hline & $11 S$ storage globulin ${ }^{g}$ & O82437_COFAR & seed storage protein & -6.795880 & 55 & 18 \\
\hline & MIP/aquaporin family protein ${ }^{g}$ & D7T7C6_VITVI & water transport & -16.886057 & 27 & 11 \\
\hline \multirow[t]{4}{*}{ G6 (19 kDa) } & small GTPase/ARF family protein & F6HHV7_VITVI & GTP binding & -20.585516 & 22 & 11 \\
\hline & jasmonate inducible protein & O04314_ARATH & lectin binding, protein folding & -14.703335 & 32 & 6 \\
\hline & putative uncharacterized protein & D7SY44_VITVI & unknown function & -11.734428 & 18 & 4 \\
\hline & putative uncharacterized protein & C6SVX3_SOYBN & stress response & -8.213248 & 18 & 3 \\
\hline G8 $(17 \mathrm{kDa})$ & heat-shock protein & B9S3B3_RICCO & small heat-shock protein & -6.531653 & 18 & 4 \\
\hline
\end{tabular}




\section{Table 4. continued}

${ }^{a}$ Band number refers to bands in Figure $4 .{ }^{b}$ Protein identification was performed using X!Tandem and sequence homology in the UniProt database restricted to spermatophyta. ${ }^{c}$ Entry name in UniProt database of the protein displaying the best sequence homology. ${ }^{d}$ Accession number in SwissProt if one exists. ${ }^{e}$ Possible function reported by UniProt/Swiss-Prot. ${ }^{f}$ Mean molecular mass calculated from all proteins grouped by a similar function as explained under Materials and Methods. ${ }^{g}$ Proteins in italics were identified using PepNovo software.

enzymes, especially oxidoreductase, kinase, and hydrolase, were associated with OBs-G. One oxidoreductase that was particularly abundant because it was identified with 24 mass spectra, displayed similarity with corticosteroid $11 \beta$-dehydrogenase. This enzyme, comprising an oil body-anchoring segment, NADPH-binding subdomain, active site, and sterolbinding subdomain, exists in seed OBs of diverse species, where it is often called steroleosin, and could be involved in sterol metabolism and in diverse signal transductions. ${ }^{32}$ In the case of G. avellana steroleosin, the highly conserved nucleotide binding site was identified. Another membrane protein associated to OBs-G was an aquaporin belonging to the MIP family and identified by de novo sequencing.

Proteins displaying highly conserved sequences in the plant kingdom could be identified despite the fact that the genomes of G. avellana and M. sativa are still not sequenced. It appeared that among the integral $\mathrm{OB}$ proteins, steroleosins and aquaporins are likely the most conserved proteins. By contrast, oleosins, which have been described in many plant species, were not identified by mass spectrometry. In these proteins, the central hydrophobic region is highly conserved, ${ }^{19}$ but contained no trypsin cleavage site, whereas $\mathrm{N}$ - and $\mathrm{C}$-terminal ends display variations even within a protein family. The high variety of OB-associated proteins identified here may reflect the in vivo interactions of OBs with glyoxysomes, protein storage vacuoles, small Golgi vesicles, mitochondria, cytoskeleton, and plasma membrane, ${ }^{16,18,45}$ thus reflecting collaboration between organelles. $^{46}$

Immunological Methods Reveal the Presence of Oleosins. Proteins from G. avellana and $M$. sativa purified seed OBs were separated by SDS-PAGE, transferred onto a PVDF membrane, and submitted to Western blotting using antibodies raised against S2, S3, and S4 oleosins from $A$. thaliana (Figure 5). It was observed that all of these specific antibodies cross-reacted with OBs-G proteins. Immunoreaction was particularly high with anti-rS2 and very low, as two faint bands, with anti-rS4. In the case of $M$. sativa, cross-reactivity was similar for anti-rS2 and anti-rS3 and lower than that observed for G. avellana. No reactivity was observed with antirS4 despite a very long time of exposure. These results indicate that oil bodies from $M$. sativa and $G$. avellana seeds contain some proteins recognized by antibodies raised against $A$. thaliana oleosin. These proteins must display some structural homology with oleosins to immunoreact with antibodies, but not enough sequence homology to be identified by mass spectrometry. Immunoblots indicated that molecular masses of proteins immunologically related to $A$. thaliana oleosins were very close, ranging from 15 to $18 \mathrm{kDa}$, with the S3-related protein being lighter and the S4-related protein being heavier. Oleosins have been classified as high or low $M_{r}$ isoforms $(H-$ and L-oleosin, respectively) depending on their relative molecular masses, ${ }^{47}$ with the A. thaliana S3 oleosin belonging to the L-form and A. thaliana S2 and S4 belonging to the $\mathrm{H}$ form. $\mathrm{H}$ - and L-oleosins are immunologically distinct; ${ }^{2}$ both forms could coexist in Madia and Gevuina seeds. High-level immunoreactions detected with OBs-G indicated that structural

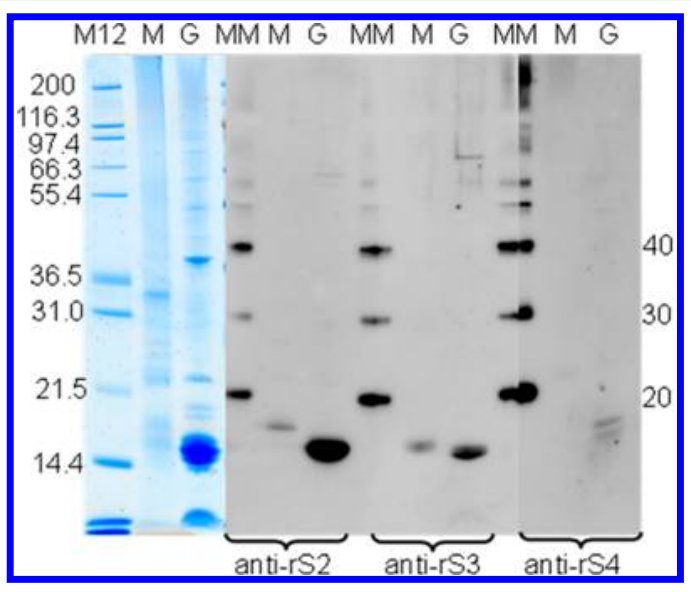

Figure 5. Immunological detection of $\mathrm{OB}$ proteins from $M$. sativa (M) or G. avellana (G) seeds with antibodies raised against oleosins S2, S3, and $\mathrm{S} 4$ from $A$. thaliana. Proteins $(5 \mu \mathrm{g})$ from purified OBs were resolved by SDS-PAGE before immunoblot analysis. The blots were probed with anti-rS2 (1:5000 dilution), anti-rS3 (1:4000), and anti-rS4 (1:2000) sera. Detection was performed using chemiluminescence. Exposure time was $6 \mathrm{~min}$ for anti-rS2 and anti-rS3 and $10 \mathrm{~min}$ for antirS4. Molecular masses are given in $\mathrm{kDa}$ using MagicMark (MM) protein standard. The panel on the left is the Coomassie-blue stained protein gel (10 or $5 \mu \mathrm{g}$ of protein) with Mark 12 (M12) as molecular mass marker.

proteins homologous to oleosins were the major protein component of these OBs. In contrast, SDS data (Figures 4 and 5 ) indicated that OBs-M contained some proteins homologous to oleosins and many other proteins. This result supported the fact that a thick coat surrounding OBs-M was visible by microscopy.

Effect of Oil Body on HUVEC Viability. OBs have been exploited as therapeutic, diagnostic, and delivery agents offering several advantages over synthetic carriers such as reduction of collateral effects and toxicity due to their natural origin. However, it is necessary to certify that OBs maintain their safety after the extraction processing from seeds for their use in food or pharmaceutical applications. For this reason, an in vitro cytotoxicity test ${ }^{48,49}$ using trypan blue ${ }^{50}$ was performed in cells to evaluate the potential toxicity of OBs. HUVEC are relatively easy to culture and provide a valuable cell model for many biology research applications. In viable cells, trypan blue is not absorbed, whereas it passes through the membrane in dead cells. As shown in Figure 6, no trypan blue staining was observed for HUVEC incubated with the OBs, indicating that cell viability was not compromised. These results are promising for possible uses of $\mathrm{OBs}$ as a delivery carrier or functional additive.

Furthermore, in this first study of the isolation and characterization of OBs from $G$. avellana and $M$. sativa, the results showed that the seeds are sources of proteins and healthy and nutritive oils very rich in unsaturated fatty acids such as oleic acid (omega 9) in G. avellana and linoleic acid (omega 6) in M. sativa. The quality of oils is related to the lipid oxidation during storage and/or food processing. One approach 


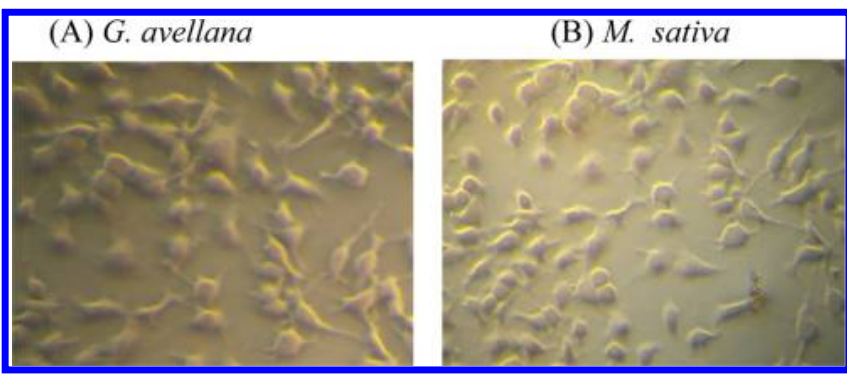

Figure 6. Effect of oil bodies from G. avellana (A) and M. sativa (B) on HUVEC viability. The images represent HUVEC with oil bodies using optical microscopy.

to protect lipid from oxidation is through microencapsulation using a polymeric matrix, which has been widely used in the food industry. OBs may be considered as a natural protection system against the oxidation of fatty acids because they safely store lipids in seeds in the form of TAGs for long periods, even under unfavorable conditions (drying, rehydration, low or high temperature, etc.). For this reason, the incorporation of undisrupted oil bodies into functional foods may prevent lipid deterioration. ${ }^{3,4}$ In this study, it was demonstrated that OBs from G. avellana and in particular from $M$. sativa represent a stable and natural emulsion system under a wide range of $\mathrm{pH}$ and ionic strengths, thus offering a natural alternative for incorporating them into food emulsion systems. Moreover, these isolated OBs did not cause any cytotoxicity in human cells. Therefore, OBs of these native seeds may be useful for the development of safe and efficient delivery carriers of bioactive molecules for food and/or pharmaceutical purposes.

\section{ASSOCIATED CONTENT}

\section{S Supporting Information}

$\mathrm{X}$ ! Tandem and PepNovo identification of OB proteins from G. avellana and $M$. sativa seeds. This material is available free of charge via the Internet at http://pubs.acs.org.

\section{AUTHOR INFORMATION}

\section{Corresponding Author}

*Phone: 56-45-325050. Fax: 56-45-325053. E-mail: facevedo@ ufro.cl.

\section{Funding}

This research was supported by funding from Conicyt through Fondecyt Project 3120022 and Project DI11-7001 and GAP technical support provided by the Research Office at the Universidad de La Frontera.

\section{Notes}

The authors declare no competing financial interest.

\section{ABBREVIATIONS USED}

OBs, oil bodies; OBs-G, oil bodies from Gevuina avellana; OBsM, oil bodies from Madia sativa; TAG, triacylglycerol; HEPES, 4-(2-hydroxyethyl)-1-piperazineethanesulfonic acid; TEM, transmission electron microscopy; FAMEs, fatty acid methyl esters; GC, gas chromatography; SDS-PAGE, sodium dodecyl sulfate-polyacrylamide gel electrophoresis; HPLC-MS/MS, liquid chromatography-tandem mass spectrometry; T, turbidity; ANOVA, analysis of variance; HUVEC, human umbilical vein endothelial cells; $K_{\mathrm{st}}$, stability constant.

\section{REFERENCES}

(1) Huang, A. H. Oil bodies and oleosins in seeds. Annu. Rev. Plant Biol. 1992, 43, 177-200.

(2) Huang, A. H. Oleosins and oil bodies in seeds and other organs. Plant Physiol. 1996, 110, 2063-2069.

(3) Iwanaga, D.; Gray, D. A.; Fisk, I. D.; Decker, E. A.; Weiss, J.; McClements, D. J. Extraction and characterization of oil bodies from soy beans: a natural source of pre-emulsified soybean oil. J. Agric. Food Chem. 2007, 55, 8711-8716.

(4) White, D. A.; Fisk, I. D.; Mitchell, J. R.; Wolf, B.; Hill, S. E.; Gray, D. A. Sunflower-seed oil body emulsions: rheology and stability assessment of a natural emulsion. Food Hydrocolloids 2008, 22, 12241232.

(5) Beisson, F.; Ferte, N.; Bruley, S.; Voultoury, R.; Verger, R.; Arondel, V. Oil-bodies as substrates for lipolytic enzymes. Biochim. Biophys Acta 2001, 1531, 47-58.

(6) White, D. A.; Fisk, I. D.; Makkhun, S.; Gray, D. A. In vitro assessment of the bioaccessibility of tocopherol and fatty acids from sunflower seed oil bodies. J. Agric. Food Chem. 2009, 57, 5720-5726.

(7) Delgado-Vargas, F.; Paredes-López, O. Natural Colorants for Food and Nutraceutical Uses; CRC Press: Boca Raton, FL, 2003; pp 113166 and 257-309.

(8) Deckers, H. M.; van Rooijen, G.; Boothe, J., et al. Sembiosys Genetics Inc. Products for topical applications comprising oil bodies. U.S. Patent 6582710, 2003.

(9) Deckers, H. M.; Van Rooijen, G.; Boothe, J.; Goll, J.; Moloney, M. M.; Schryvers, A. B. et al. Sembiosys genetics inc. immunogenic formulations comprising oil bodies. U.S. Patent 6761914, 2004.

(10) Moloney, M. M. Sembiosys Genetics Inc. Oil-body proteins as carriers of high-value peptides in plants. U.S. Patent 5650554, 1997.

(11) Boucher, J.; Cengelli, F.; Trumbic, D.; Marison, I. W. Sorption of hydrophobic organic compounds (HOC) in rapeseed oil bodies. Chemosphere 2008, 70, 1452-1458.

(12) Fisk, I. D.; Linforth, S. T.; Taylor, A. J.; Gray, D. A. Aroma encapsulation and aroma delivery by oil body suspensions derived from sunflower seeds (Helianthus annus). Eur. Food Res. Technol. 2011, 232, 905-910.

(13) Hou, R. C. W.; Lin, M. Y.; Wang, M. M. C.; Tzen, J. T. C. Increase of viability of entrapped cells of Lactobacillus delbrueckii ssp. bulgaricus in artificial sesame oil emulsions. J. Dairy Sci. 2003, 86, 424-428.

(14) Jolivet, P.; Roux, E.; d'Andréa, S.; Davanture, M.; Negroni, L.; Zivy, M.; Chardot, T. Protein composition of oil bodies in Arabidopsis thaliana ecotype WS. Plant Physiol. Biochem. 2004, 42, 501-509.

(15) Popluechai, S.; Froissard, M.; Jolivet, P.; Breviario, D.; Gatehouse, A. M. R.; Donnell, A. G. O.; Chardot, T.; Kohli, A. Jatropha curcas oil body proteome and oleosins: L-form JcOle3 as a potential phylogenetic marker. Plant Physiol. Biochem. 2011, 49, 352356.

(16) Tnani, H.; Lopez, I.; Jouenne, T.; Vicient, C. M. Protein composition analysis of oil bodies from maize embryos during germination. J. Plant Physiol. 2011, 168, 510-513.

(17) Cummins, I.; Murphy, D. J. cDNA sequence of a sunflower oleosin and transcript tissue specificity. Plant Mol. Biol. 1992, 19, 873876.

(18) Katavic, V.; Agrawal, G. K.; Hajduch, M.; Harris, S. L.; Thelen, J. $\mathrm{J}$. Protein and lipid composition analysis of oil bodies from two Brassica napus cultivars. Proteomics 2006, 6, 4586-4598.

(19) Jolivet, P.; Boulard, C.; Bellamy, A.; Larre, C.; Barre, M.; Rogniaux, H.; d'Andrea, S.; Chardot, T.; Nesi, N. Protein composition of oil bodies from mature Brassica napus seeds. Proteomics 2009, 9, $3268-3284$.

(20) Kalinski, A.; Loer, D. S.; Weisemann, J. M.; Matthews, B. F.; Herman, E. M. Isoforms of soybean seed oil body membrane protein $24 \mathrm{kDa}$ oleosin are encoded by closely related cDNAs. Plant Mol. Biol. 1991, 17, 1095-1098.

(21) Bertoli, C.; Fay, L. B.; Stancanelli, M.; Gumy, D.; Lambelet, P. Characterization of Chilean hazelnut (Gevuina avellana Mol) seed oil. J. Am. Oil Chem. Soc. 1988, 75, 1037-1040. 
(22) Schmeda-Hisrchmann, G. Madia sativa, a potential oil crop of central Chile. Econ. Bot. 1995, 49, 257-259.

(23) Ibaca, R. Monografia de Árboles y Arbustos Chilenos con Propiedades Medicinales y Aromáticas; Facultad de Ciencias Forestales, Universidad de Concepción: Concepción, Chile, 2001; p 246

(24) Facciola, S. Cornupia-un libro de la Fuente de Plantas Comestibles; Publicaciones de Kampong, 1990; ISBN 0-9628087-0-9.

(25) Jolivet, P.; Boulard, C.; Bellamy, A.; Valot, B.; d'Andréa, S.; Zivy, M.; Nesi, N.; Chardot, T. Oil body proteins sequentially accumulate throughout seed development in Brassica napus. J. Plant Physiol. 2011, 168, 2015-2020.

(26) Allen, D. K.; Tao, B. Y. Kinetic characterization of enhanced lipid activity on oil bodies. Bioprocess. Biosyst. Eng. 2007, 30, 271-279.

(27) Zhuang, X.; Tlalka, M.; Davies, D. S.; Allaway, W. G.; Watkinson, S. C.; Ashford, A. E. Spitzenkörper, vacuoles, ring-like structures, and mitochondria of Phanerochaete velutina hyphal tips visualized with carboxy-DFFDA, CMAC and $\operatorname{DiOC}_{6}(3)$. Mycol. Res. 2009, 113, 417-431.

(28) Folch, J.; Lees, M.; Sloane Stanley, G. H. A simple method for the isolation and purification of total lipids from animal tissues. J. Biol. Chem. 1957, 226, 497-509.

(29) Landry, J.; Delhaye, S. A simple and rapid procedure for hydrolyzing minute amounts of proteins with alcali. Anal. Biochem. 1996, 243, 191-194.

(30) Laemmli, U. K. Cleavage of structural proteins during the assembly of the head of bacteriophage T4. Nature 1970, 227, 680685.

(31) Neuhoff, V.; Arold, N.; Taube, D.; Ehrhardt, W. Improved staining of proteins in polyacrylamide gels including isoelectric focusing gels with clear background at nanogram sensitivity using Coomasie Brilliant Blue G-250 and R-250. Electrophoresis 1988, 9, $255-262$.

(32) d'Andréa, S.; Canonge, M.; Beopoulos, A.; Jolivet, P.; Hartmann, M. A.; Miquel, M.; Lepiniec, L.; Chardot, T. At5g50600 encodes a member of the short-chain dehydrogenase reductase superfamily with $11 \beta$ - and $17 \beta$-hydroxysteroid dehydrogenase activities associated with Arabidopsis thaliana seed oil bodies. Biochimie 2007, 89, 222-229.

(33) Tzen, J. T. C.; Huang, A. H. C. Surface structure and properties of plant seed oil bodies. J. Cell Biol. 1992, 117, 327-335.

(34) Jaffe, E. A.; Nachman, R. L.; Becker, C. G.; Minic, C. R. Culture of human endothelial cells derived from umbilical veins. J. Clin. Invest. 1973, 52, 2745-2756.

(35) Childers, N. K.; Michalek, S. M.; Eldridge, J. H.; Denys, F. R.; Berry, A. K.; McGhee, J. R. Characterization of liposome suspensions by flow cytometry. J. Immunol. Methods 1989, 119, 135-143.

(36) Macey, M. G. Flow Cytometry. Principles and Applications; Macey, M. G., Ed.; Humana Press: Totowa, NJ, 2007; pp 290.

(37) Plattner, R. D.; Kleiman, R. Grevillea robusta seed oil: a source of $\omega-5$ monoenes. Phytochemistry 1977, 16, 255-256.

(38) Vickery, J. R. The fatty acid composition of the seed oils of Proteaceae: a chemotaxonomic study. Phytochemistry 1971, 10, 123130.

(39) Bombarda, I.; Zongo, C.; McGill, C. R.; Doumenq, P.; Fogliani, B. Fatty acids profile of Alphitonia neocaledonica and Grevillea exul var. rubiginosa seed oils, occurrence of an $\omega 5$ series. J. Am. Oil Chem. Soc. 2010, 87, 981-986.

(40) Frandsen, G.; Mundy, J.; Tzen, T. C. Oil bodies and their associated proteins, oleosin and caleosin. Physiol. Plant. 2007, 112, 301.

(41) Tzen, J. T. C.; Peng, C. C.; Cheng, D. J.; Chen, E. C. F.; Chiu, J. M. H. A new method for seed oil body purification and examination of oil body integrity following germination. J. Biochem. 1997, 121, 762768.

(42) Fujimoto, Y.; Itabe, H.; Sakai, J.; Makita, M.; Noda, J.; Mori, M.; Higashi, Y.; Kojima, S.; Takano, T. Identification of major proteins in the lipid droplet-enriched fraction isolated from the human hepatocyte cell line HuH7. Biochim. Biophys. Acta 2004, 1644, 47-59.

(43) Athenstaedt, K.; Jolivet, P.; Boulard, C.; Negroni, L.; Zivy, M.; Nicaud, J.-M.; Chardot, T. Lipid particle composition of the yeast
Yarrowia lipolytica depends on the carbon source. Proteomics 2006, 6, $1450-1459$

(44) Maurel, C.; Verdoucq, L.; Luu, D. T.; Santoni, V. Plant aquaporins: membrane channels with multiple integrated functions. Annu. Rev. Plant Biol. 2008, 59, 595-624.

(45) Marmagne, A.; Ferro, M.; Meinnel, T.; Bruley, C.; Kuhn, L.; Garin, J.; Barbier-Brygoo, H.; Ephritikhine, G. A high content in lipidmodified peripheral proteins and integral receptor kinases features in the arabidopsis plasma membrane proteome. Mol. Cell. Proteomics 2007, 6, 1980-1996.

(46) Agrawal, G. K.; Bourguignon, J.; Rolland, N.; Ephritikhine, G.; Ferro, M.; Jaquinod, M.; Alexiou, K. G.; Chardot, T.; Chakraborty, N.; Jolivet, P.; Doonan, J. H.; Rakwal, R. Plant organelle proteomics: collaborating for optimal cell function. Mass Spectrom. Rev. 2011, 30, $772-853$.

(47) Tzen, J. T.; Lai, Y. K.; Chan, K. L.; Huang, A. H. Oleosin isoforms of high and low molecular weights are present in the oil bodies of diverse seed species. Plant Physiol. 1990, 94, 1282-1289.

(48) Ridolfi, D. M.; Marcato, P. D.; Machato, D.; Silva, R. A.; Justo, G. Z.; Durán, N. In vitro cytotoxicity assays of solid lipid nanoparticles in epitelial and dermal cells. J. Physics: Conf. Ser. 2011, 304, 012032.

(49) Sini, K. R.; Haribabu, Y.; Sajoth, M. S.; Surya Sreekumar, K. In vitro cytotoxic activity of orthosophon thymiflrus Roth, sleensen lead extract against Dalton lymphoma ascites cell lines. J. Chem. Pharm. Res. 2012, 4, 917-921.

(50) Palama, I. E.; Muraso, M.; Coluucia, A.; D'Amone, S.; Giglil, G. Cell uptake and validation of novel PECs for biomedical applications. J. Drug Delivery 2011, 1-7, DOI: 10.1155/2011/203676. 